\title{
Nutritional Status of Elderly People Living at Home in Sidi-Bel-Abbes (West Algeria)
}

\author{
N. Menadi ${ }^{1}$, M. B. Khaled ${ }^{1}$, B. Merrakchi ${ }^{2}$, S. Belbraouet ${ }^{3 *}$ \\ ${ }^{1}$ Department of Biology, Faculty of Sciences, Djilali Liabes University of Sidi-Bel-Abbès, Sidi-Bel-Abbès, Algeria; ${ }^{2}$ Department of \\ General Medicine, Sidi-Lahcen Health Center, Sidi-bel-Abbès, Algeria; ${ }^{3}$ University of Moncton, Ecole des Sciences des Aliments de \\ Nutrition et des Etudes Familiales Moncton, Canada. \\ Email: "slimane.belbraouet@umoncton.ca
}

Received May $8^{\text {th }}, 2013$; revised June $8^{\text {th }}, 2013$; accepted June $15^{\text {th }}, 2013$

Copyright (C) 2013 N. Menadi et al. This is an open access article distributed under the Creative Commons Attribution License, which permits unrestricted use, distribution, and reproduction in any medium, provided the original work is properly cited.

\begin{abstract}
The aim of the study was to assess the nutritional status of a cohort of elderly people living independently at home. 314 elderly individuals were selected during general medicine examinations. The collection of nutritional data concerned the measurement of some anthropometric parameters (body weight, height, and BMI), the Mini Nutritional Assessment (MNA) and serum albumin. The average age was $72.92 \pm 6.26$ years with a feminine predominance (59.55\%). The BMI was $25.63 \pm 4.43 \mathrm{Kg} \cdot \mathrm{m}^{-2}$ and serum albumin $36.45 \pm 5.77 \mathrm{~g} \cdot \mathrm{L}^{-1} .61 \%$ of the investigated population were affected by chronic diseases such as: diabetes (39\%). Using the MNA as a mean of screening; $46.18 \%$ of individuals presented a risk of malnutrition and $4.78 \%$ were undernourished. However, when the BMI and serum albumin were used; $14.01 \%$ and $42.35 \%$ have been considered as undernourished respectively. The MNA seems to be a more sensitive tool rather than the other screening parameters (BMI and serum albumin) in the assessment of nutritional risk in the elderly.
\end{abstract}

Keywords: Elderly; Nutritional Status; Anthropometric Parameters; Mini Nutritional Assessment; Albumin

\section{Introduction}

There are several consequences of malnutrition which are potentially serious among elderly individuals. The screening and the assessment of malnutrition hazards are seldom undertaken either in institution or at home [1,2].

Many authors have shown the interest of diagnosing malnutrition and have suggested different tools for assessing the nutritional status of ageing people $[3,4]$. Often the measure of anthropometric and biological parameters is used [1]. Some nutritional parameters such as: the body weight, BMI and serum albumin are sufficient for the screening and the diagnosis [5]. Furthermore, the screening could be achieved using the Mini Nutritional Assessment (MNA) questionnaire developed by Guigoz et al. [6]. The MNA has been widely used in the assessment of the risk of malnutrition among different categories of elderly people: hospitalized individuals, in preoperative period, in convalescence, retirement home or at home [7].

To assess the nutritional risk in the elderly, body weight, height, BMI, serum albumin, and MNA were

\footnotetext{
${ }^{*}$ Corresponding author.
}

evaluated in a cohort of elderly people living independently at home in Sidi-bel-Abbes city (West Algeria).

\section{Subjects and Methods}

The study lasted five months June-October 2011 in the Department of General Medicine of Sidi-Lahcen Health Center (Sidi-bel-Abbes). The protocol was approved by the Sidi-Lahcen Health Center Committee for Research on Human Subjects. The purpose of the study was explained to all participants and investigation was carried out with their written consent. The investigated cohort was selected during general medicine examinations and composed of elderly individuals aged over 65 years living at home. The exclusion criteria were people aged less than 65 years, disabled individuals and lack of verbal communication, people unable to measure their anthropometric parameters, and those who refused to participate.

A total of 314 individuals were selected and met the predefined inclusion criteria: age $\geq 65$ years, both sexes. Doctors' cabinets of the medical establishment in SidiLahcen (Sidi-bel-Abbes, Algeria) served as places of recruitment of patients. The socio-demographic and 
anthropometric data as well as the MNA were collected using a questionnaire during interview session. The body weight was measured with a minimum of clothing using an electronic scale (SECA, Germany) with an accuracy of $\pm 50 \mathrm{~g}$. The height was measured in a vertical position, without shoes and heels together with a stadiometer for wall mounting. BMI was calculated as the weight $(\mathrm{Kg})$ divided by the square of the height $(\mathrm{m})$. The MNA score was calculated for each individual. The serum albumin dosage was done using the colorimetric method (bromocresol green) [8]. On the other hand, the chronic diseases were diagnosed by physicians.

Concerning the BMI, categories defined by the WHO [9] are as follow: underweight (BMI < 18.5), normal weight (BMI: 18.5 - 24.99), overweight (BMI: 25 - 29.99) and obese $(\mathrm{BMI} \geq 30)$. Malnutrition is determined when the serum albumin rate is less than $35 \mathrm{~g} \cdot \mathrm{L}^{-1}$ and/or BMI $<21 \mathrm{Kg} / \mathrm{m}^{2}$ and MNA $<17$. Malnutrition is considered as severe when serum albumin $<30 \mathrm{~g} \cdot \mathrm{L}^{-1}$ or a $\mathrm{BMI}<18$ $\mathrm{Kg} \cdot \mathrm{m}^{-2}$. The risk of malnutrition was assessed by the MNA screening score of 17 - 23.50 [5,10,11].

Data analysis was performed using Statview program 5.0 (SAS Institute) [12]. Results of anthropometric parameters, biological and nutritional index were interpreted using previously established reference intervals in the elderly. Comparison between the two groups of gender was done using paired Student's- $t$ test for comparison of means, after checking the normal distribution of our sample. Simple regression analysis was used to calculate the correlation coefficient between variables. A significance level of $\mathrm{p}<0.05$ was used. Qualitative variables are presented as numbers and percentages.

\section{Results}

314 individuals have been recruited among them 187 women (W) and 127 men (M) with an average of $72.92 \pm$ 6.26 year-old (Table 1). No significant difference $(\mathrm{p}>$ $0.05)$ was observed between the age of women $(72.40 \pm$ 06.08 years) and men ( $73.69 \pm 6.45$ years). $94.90 \%$ of the studied cohort live with their families and $5.10 \%$ live alone. Concerning the chronic diseases, $61 \%$ of the study population were affected: diabetes $(39 \%)$, hypertension (13\%), cardiovascular diseases $(3 \%)$ and $6 \%$ other chronic diseases such as rheumatism (4\%), asthma (1\%) and renal failure (1\%). The average body weight was of $64.20 \pm 12.35 \mathrm{~kg}(\mathrm{~W}: 62.15 \pm 11.22 \mathrm{~kg}, \mathrm{M}: 67.21 \pm$ $13.33 \mathrm{~kg})$, the average height was $158 \pm 9 \mathrm{~cm}(\mathrm{~W}: 153 \pm$ $6 \mathrm{~cm}, \mathrm{M}: 166 \pm 7 \mathrm{~cm})$. The BMI was of $25.63 \pm 4.43$ $\mathrm{kg} \cdot \mathrm{m}^{-2}$. Significant differences were noticed between men and women for body weight, height, BMI and MNA $(\mathrm{p}<0.05)$. However, no significant difference was found for serum albumin levels between the two sexes.

According to the WHO's classification of the BMI, we found that $4.14 \%$ of the studied cohort were considered as underweight individuals. $40.80 \%$ were normal weight.

Table 1. Characteristics, anthropometric parameters, serum albumin and MNA of the studied population.

\begin{tabular}{lccc}
\hline & $\begin{array}{c}\text { Total population } \\
\mathrm{n}=314\end{array}$ & $\begin{array}{c}\text { Women } \\
\mathrm{n}=187\end{array}$ & $\begin{array}{c}\text { Men } \\
\mathrm{n}=127\end{array}$ \\
\hline Healthy (\%) & 39 & 33 & 48 \\
Diseased (\%) & 61 & 67 & 52 \\
$\quad$ Diabetes (\%) & 39 & 44 & 30 \\
$\quad$ Hypertension (\%) & 13 & 13 & 13 \\
$\quad$ CVD (\%) & 3 & 3 & 3 \\
$\quad$ Others (\%) & 6 & 7 & 6 \\
Age (year) & $72.92 \pm 6.26$ & $72.40 \pm 6.08$ & $73.69 \pm 6.45$ \\
Body Weight (Kg) & $64.20 \pm 12.35$ & $62.15 \pm 11.22^{*}$ & $67.21 \pm 13.33$ \\
Height (cm) & $158 \pm 9$ & $153 \pm 6^{*}$ & $166 \pm 7$ \\
BMI (Kg $\mathbf{m}^{-2}$ ) & $25.63 \pm 4.43$ & $26.55 \pm 4.22^{*}$ & $24.29 \pm 4.39$ \\
Serum albumin (g. $\left.\mathbf{L}^{-1}\right)$ & $36.45 \pm 5.77$ & $36.52 \pm 5.62$ & $36.35 \pm 5.99$ \\
MNA & $16.72 \pm 7.09$ & $17.29 \pm 4.17^{*}$ & $15.89 \pm 3.86$ \\
MNA $<17(\%)$ & 4.78 & 3.74 & 6.30 \\
MNA 17 - 23.5 (\%) & 46.18 & 52.40 & 37.00 \\
MNA $>$ 23.50 (\%) & 49.04 & 43.86 & 56.70 \\
\hline
\end{tabular}

* p < 0.05; CVD: cardiovascular diseases; BMI: Body mass index; MNA: Mini Nutritional Assessment. 
However, $39.50 \%$ and $15.61 \%$ belonged to overweight and obese categories respectively.

Table 2 shows the prevalence of malnutrition when we used BMI, albumin and MNA as tools of screening. The average BMI of the whole studied cohort was 25.63 \pm 4.43 . Malnutrition (BMI $<21 \mathrm{Kg} / \mathrm{m}^{2}$ ) affected $14.01 \%$ (W: $8.55 \%$, M: $22.04 \%$ ). On the other hand, severe malnutrition concerned $3.50 \%$ (W: $1.60 \%$, M: $6.30 \%$ ). For serum albumin, no significant difference was detected between women $\left(36.52 \pm 5.62 \mathrm{~g} \cdot \mathrm{L}^{-1}\right)$ and men $(36.35 \pm$ $\left.5.99 \mathrm{~g} \cdot \mathrm{L}^{-1}\right)$. The frequency of malnutrition observed in the studied cohort, using serum albumin as a screening tool, showed that $42.35 \%$ (W: $42.25 \%$, M: $42.52 \%$ ) were undernourished i.e. albumin $<35 \mathrm{~g} \cdot \mathrm{L}^{-1} \cdot 12.42 \%$ (W: $9.63 \%$, M: $16.53 \%$ ) were severely undernourished i.e. albumin $<30 \mathrm{~g} \cdot \mathrm{L}^{-1}$. Whereas, when the MNA was used as screening tool, it allowed us to categorize three subgroups: undernourished (MNA < 17); 4.78\% (W: 3.74\%, M: $6.30 \%)$, at risk of malnutrition $(17<$ MNA $<23.50)$; 46.18\% (W: $52.40 \%$, M: $37.00 \%$ ), and without malnutrition (MNA > 23.50); 49.04\% (W: 43.86\%, M: 56.70\%).

The simple regression analysis showed that, in both sexes, the age was negatively correlated to some anthropometric parameters: height, weight, BMI, and serum albumin. However, it was positively correlated with MNA as shown in Table 3.

\section{Discussion}

First of all, this study has put diabetes in first position, as the most frequent disease, among the chronic diseases which are affecting our studies population. The high prevalence of diabetes $(39.00 \%)$ has not been reported in any study according to our knowledge, and remains higher to that found by Bourdel-Marchasson et al. [13] and Muller et al. [14] who stated that the prevalence of diabetes, in industrialized countries, generally stabilizes at around of $10 \%$ after age 65 . Belbraouet et al. [15] reported a prevalence of diabetes of $11.53 \%$ in a cohort of French elderly women.

In women, the BMI values were similar to those found in Italian [16] and Spanish cohorts [17]. Though, MNA and serum albumin values obtained were lower than those reported by Lauqué et al. [18] in a population of elderly people living at home.

The prevalence of malnutrition in the elderly people living at home, in the use of BMI as a screening tool, was higher in the current studied cohort compared to that reported in the literature $(5 \%-10 \%)[19,20]$. Additionally, this prevalence was also higher in comparison to that found by Mowe et al. [19] and Lumbers et al. [21] in Norway (5.3\%) and Great Britain (2\%). It should be mentioned that the prevalence of malnutrition is more common among men than women $(22.04 \%$ vs. $8.55 \%)$ as it was reported by Elasmi-Allal et al. [22].

Concerning the prevalence of obesity, our results have revealed a significant difference between $\mathrm{W}: 20.86 \%$ and M: $10.00 \% ; p<0.05$. This finding is similar to that reported by ObEpi survey [23], which indicated that $16.50 \%$ of individuals over 65 were obese. Further works led to similar results [13,24]. Elasmi-Allal et al. [22] reported an overweight prevalence of $40 \%$ in women living independently and Serra et al. [17] showed, in a cohort of elderly people living at home, that $37 \%$ of women and $16 \%$ of men had a BMI exceeding 30 .

Afterwards, when we used the MNA as a screening tool (MNA < 17), the prevalence of malnutrition was for W: $3.74 \%$ and for M: $6.30 \%$. The risk of malnutrition was much higher than that reported in the literature [25]. Women were more affected $(52.40 \%)$ to the risk of malnutrition than men $(37.00 \%)$. These results agree with

Table 2. Prevalence of malnutrition using BMI, serum albumin, and MNA.

\begin{tabular}{|c|c|c|c|c|}
\hline & $\begin{array}{l}\text { Total Population } \\
\qquad \mathrm{n}=314\end{array}$ & $\begin{array}{l}\text { Women } \\
\mathrm{n}=187\end{array}$ & $\begin{array}{c}\text { Men } \\
\mathrm{n}=127\end{array}$ & p-value \\
\hline \multicolumn{5}{|l|}{ Risk of malnutrition \% } \\
\hline MNA: 17 - 23.50 & 46.18 & 52.40 & 37.00 & $<0.05$ \\
\hline \multicolumn{5}{|l|}{ Moderate malnutrition \% } \\
\hline $\mathrm{BMI}<21 \mathrm{Kg} \cdot \mathrm{m}^{-2}$ & 14.01 & 8.55 & 22.04 & $<0.05$ \\
\hline Serum albumin $<35 \mathrm{~g} \cdot \mathrm{L}^{-1}$ & 42.35 & 42.25 & 42.52 & NS \\
\hline MNA $<17$ & 4.78 & 3.74 & 6.30 & $<0.05$ \\
\hline \multicolumn{5}{|l|}{ Severe malnutrition \% } \\
\hline $\mathrm{BMI}<18 \mathrm{Kg} \cdot \mathrm{m}^{-2}$ & 3.50 & 1.60 & 6.30 & $<0.05$ \\
\hline Serum albumin $<30 \mathrm{~g} \cdot \mathrm{L}^{-1}$ & 12.42 & 9.63 & 16.53 & $<0.05$ \\
\hline
\end{tabular}

BMI: Body mass index; MNA: Mini Nutritional Assessment; NS: non-significant. 
Table 3. Correlation coefficient between age, MNA, anthropometric parameters, and serum albumin.

\begin{tabular}{|c|c|c|c|c|c|c|}
\hline & $\begin{array}{c}\text { Age } \\
\text { (year) }\end{array}$ & $\begin{array}{c}\text { Body } \\
\text { weight } \\
(\mathrm{Kg})\end{array}$ & $\begin{array}{c}\text { Height } \\
(\mathrm{cm})\end{array}$ & $\begin{array}{c}\text { BMI } \\
\left(\mathrm{Kg} \cdot \mathrm{m}^{-2}\right)\end{array}$ & $\underset{\left(\mathrm{g} \cdot \mathrm{L}^{-1}\right)}{\mathbf{S A}}$ & MNA \\
\hline \multicolumn{7}{|c|}{ Women } \\
\hline Age (year) & - & -0.258 & -0.170 & -0.211 & -0.093 & 0.096 \\
\hline MNA & 0.096 & -0.168 & -0.150 & -0.110 & -0.091 & - \\
\hline \multicolumn{7}{|c|}{ Men } \\
\hline Age (year) & - & -0.236 & -0.306 & -0.077 & -0.200 & 0.216 \\
\hline MNA & 0.216 & -0.295 & -0.107 & -0.262 & -0.093 & - \\
\hline
\end{tabular}

BMI: Body mass index; MNA: Mini Nutritional Assessment; SA: serum albumin.

those found by Kézachian \& Bonnet [26] who observed in a population of elderly people living at home, that the prevalence of risk of malnutrition using the MNA as a screening tool was higher in women than men (19.8\% vs. $13.6 \%)$.

As for screening of malnutrition using serum albumin, the prevalence was similar in both sexes (W: $42.25 \% \mathrm{M}$ : $42.52 \%)$.Severe malnutrition was higher in $M: 16.53 \%$ than W: $9.63 \%$. The prevalence of severe malnutrition is higher in our elderly people living at home comparing with literature data [27].

In agreement with Vellas et al. [28], the MNA was correlated only with age of patients. Whereas, no correlation has been noticed between MNA, the anthropometric parameters, and serum albumin. These findings arein agreement with those found by Chumlea et al. [29] and in disagreement with Salleti et al.'s findings [30]. In both sexes, the anthropometric parameters and the serum albumin were inversely correlated with age of individuals. While, in older individuals ( $>85$ year-old) values were lower. These results agree to those found by Belbraouet et al. [15]. BMI was inversely correlated with age of $\mathrm{W}$ : -0.211 and $\mathrm{M}:-0.077$. This was confirmed by Tavitianet et al. [31] who showed among 251 elderly French individuals that BMI was inversely correlated with age. Launeret al. [32] reported that the average BMI tended to decrease significantly with age.

Concerning serum albumin, it was inversely correlated with age in $\mathrm{W}:-0.093$ and $\mathrm{M}:-0.200$. These results agree with those of Klonnoff-Cohen et al. [33] in a US population of elderly men and women living at home.

It is well known that the prevalence of nutritional risk and malnutrition vary according to the screening tool used aiming to identify people at nutritional risk or undernourished so they can benefit from medical care [26]. In the current study, the use of MNA, as a tool of screening, was more sensitive than the use of BMI and serum albumin in the detection of people at risk of mal- nutrition. This was confirmed by Vellas et al. [34] and Guigoz \& Vellas [35], who showed that the MNA was more sensitive than serum albumin in the detection of individuals at risk of malnutrition. Tavitian et al. [31] reported that the MNA seems to be a good indicator since it is clearly correlated with the levels of serum albumin. However, albumin seems to be a more relevant marker than BMI in screening undernourished patients (42.35\% vs. $14.01 \%)$.

\section{Acknowledgements}

Authors want to thank the staff of department of general medicine of Sidi-Lahcen Health Center (Sidi-bel-Abbes), especially medical supervisor, GPs and staff analysis laboratory for valuable assistance of this study.

\section{REFERENCES}

[1] C. Dagorne, S. David, E. Alix, D. Girard, G. Bouzillé, A. Tallec and S. Fanello, "Prévention et Prise en Charge de la Malnutrition dans les EHPAD," Cahiers de Nutrition et Diététique, Vol. 46, No. 3, 2011, pp. 137-144. doi:10.1016/j.cnd.2011.02.001

[2] M. Bernard, C. Aussel and L. Cynober, "Marqueurs de la Malnutrition et son Risque ou Marqueurs des Complications Liées à la Malnutrition," Nutrition Clinique et Métabolique, Vol. 21, No. 1, 2007, pp. 52-59. doi:10.1016/j.nupar.2007.01.009

[3] K. S. Kubena, W. A. McIntosh, M. B. Giorghiades and W. A. Landmann, "Anthropometry and Health in the Elderly," Journal of American Dietetic Association, Vol. 9, No. 11, 1991, pp. 1402-1407.

[4] M. J. Kergoat, B. S. Leclerc, C. Petit Clerc and A. Imbach, "Discriminant Biochemical Markers for Evaluating the Nutritional Status of Elderly Patients in Long-Term Care," American Journal of Clinical Nutrition, Vol. 46, No. 5, 1987, pp. 849-861.

[5] A. Raynaud-Simon, "Comment Dépister la Malnutrition chez la Personne Agée?" Médecine des Maladies Métaboliques, Vol. 3, No. 4, 2009, pp. 365-369.

[6] Y. Guigoz and B. Vellas, “Test d'Évaluation de l'État Nutritionnel de la Personne Agée: Le Mini Nutritional Assessment (MNA)," Médecine et Hygiène, Vol. 53, No. 2087, 1995, pp. 1965-1969.

[7] B. Vellas, H. Villars, G. Abellan, M. Soto, Y. Rolland, Y. J. E. Guigoz, W. Chumlea, A. Salva, L. Z. Rubenstein and P. Garry, "Overwiew of the MNA. Its History and Challenges," Journal of Nutrition and Health Aging, Vol. 10, No. 6, 2006, pp. 456-463.

[8] B. T. Doumas, W. A. Watson and H. G. Biggs, "Albumin Standards and the Measurement of Serum Albumin with Bromocresol Green," Clinica Chimica Acta, Vol. 3, No. 1, 1997, pp. 21-30. doi:10.1016/S0009-8981(96)06447-9

[9] OMS, "Obésité et Surpoids," Aide-Mémoire No. 311, 2013. www.who.int/mediacentre/factsheets/fs311/fr/ 
[10] F. Blonde-Cynober and C. Aussel, "Définition des Intervalles de référence des Seuils Décisionnels chez les Sujets Agés: Cas de l'Évaluation de l'État Nutritionnel," Biotribune, Vol. 35, No. 1, 2010, pp. 15-19.

[11] C. Patry and A. Raynaud-Simon, "Prise en Charge de la Malnutrition chez les Personnes Agées: Quoi de Neuf Depuis les Recommandations de l'HAS en 2007," Neurologie-Psychiatrie-Gériatrie, Vol. 11, No. 63, 2011, pp. 95-100.

[12] J. Caldorola, A. Dilmaghani, J. Gagnon, C. Soper and E. Wasserman, "Statview for Windows," Version 5, SAS Institut Inc., Cary, 1998.

[13] I. Bourdel-Marchasson and T. Traissac, "Place et Impact des Régimes chez les Personnes les Plus Agées," $\mathrm{Nu}$ trition Clinique et Métabolique, Vol. 18, No. 4, 2004, pp. 224-230.

[14] H. Muller, B. Denis, C. Valentin and L. Teillet, "Human Ageing: Demographic Trends and Medical Implications," Nutrition Clinique et Métabolique, Vol. 18, No. 4, 2004, pp. 171-174. doi:10.1016/j.nupar.2004.10.004

[15] S. Belbraouet, N. Chau, A. Tebi and G. Debry, "Anthropometric Characteristics of Hospitalized Elderly Women: A Case-Control Study," International Journal of Environmental Research and Public Health, Vol. 8, No. 7, 2011, pp. 2584-2592. doi:10.3390/ijerph8072584

[16] M. Gatto, E. M. Inelmen, S. Ferrari, G. F. Jimenez, P. L. Bisbini and G. Enzi, "Nutrients Intake in Elderly: Descriptive Results of a Cross-Sectional Study," Age \& Nutrition, Vol. 6, No. 1, 1996, pp. 17-23.

[17] J. A. Serra, E. Baeza, A. J. Cruz-Jentoft, P. Alcalade, A. Sanchez-Diez, S. Romeo, L. Cabrerizo and J. M. Ribera, "Nutritional Status and Nutritional Intake in Non-Hospitalized Elderly," Age \& Nutrition, Vol. 4, No. 2, 1993, pp. 82-87.

[18] S. Lauque, G. Reyes, C. Faisant, B. Vellas and J. L. Albaréde, "Etude des Corrélations entre l'Évaluation du Statut Nutritionnel par le MNA et l'Association Albumine Plasmatique et Anthropométrique," Symposium International on Nutrition des Personnesâgées, CERIN, 1997, p. 319.

[19] M. Mowé, T. Bohmer and E. Kindt, "Reduced Nutritional Status in an Elderly Population (>70 y) is Probable before Disease and Possibly Contributes to the Development of Disease," American Journal of Clinical Nutrition, Vol. 59, No. 2, 1994, pp. 317-324.

[20] D. Noel, "Stratégie Nutritionnelle en Médecine Gériatrique," Louvain Médecine, Vol. 117, No. 3, 1998, pp. S47-S51.

[21] M. Lumbers, A. S. New, S. Gibson and M. C. Murphy, "Nutritional Status in Elderly Female Hip Fracture Patients: Comparison with an Age-Matched Home Living Group Attending Day Centers," British Journal of Nutrition, Vol. 85, No. 6, 2001, pp. 733-740. doi:10.1079/BJN2001350

[22] M. Elasmi-Allal, H. Sanhadji, R. Jemma, A. Jemma, N. Kaabachi and A. Mebazaa, "Etude de l'État Nutritionnel des Personnes Agées dans deux Populations Tunisiennes Séjournant à Domicile ou en Institution," Revue de
Gériatrie, Vol. 28, No. 1, 2003, pp. 39-36.

[23] J. L. Schlienger, F. Luca and A. Pradignac, "Particularité de l'Obésité chez la Personne Âgée," Médecine des maladies Métaboliques, Vol. 3, No. 4, 2009, pp. 375-379.

[24] E. Macia, G. Boetsch and N. Chauis-Lucciani, "Étude Anthropométrique du Vieillissement dans une Population âgée Française (Marseille): Relation entre l'Âge, l'Indice de Masse Corporelle, Acuité visuelle et des Facteurs Socio-Psychologiques," Antropo, Vol. 7, 2008, pp. 113122. www.didac.ehu.es/antropo

[25] R. Visvanathan, C. Macintosh, M. Callary, L. Penhal, M. Horowitz and I. Chapman, "The Nutritional Status of 250 Older Australian Recipients of Domiciliary Care Services and Its Association Outcomes at 12 Months," Journal of American Geriatric Society, Vol. 51, No. 7, 2003, pp. 1007-1011. doi:10.1046/j.1365-2389.2003.51317.x

[26] L. Kézachian and P. A. Bonnet, "Simplifying Screening Process of Elderly Malnutrition in General Practice: Test Match between a Simple Tool, the 'Malnutrition Universal Screening Tool' (MUST) and the 'Mini Nutritional Assessment-Short Form' (MNA-SF)," Nutrition Clinique et Métabolique, Vol. 26, No. 3, 2012, pp. 109-113. doi:10.1016/j.nupar.2012.07.004

[27] G. Debry, "La Malnutrition Protéino-Energétique des Personnes Agées," Gériatrie, Vol. 36, No. 11, 1986, pp. 617-626.

[28] B. Vellas, Y. Guigoz, M. Baumgartner, P. J. Garry, S. Lauque and J. L. Albarède, "Relationships between Nutritional Markers and the Mini Nutritional Assessment in 155 older persons," Journal of American Geriatric Society, Vol. 48, No. 10, 2000, pp. 1300-1309.

[29] W. C. Chumlea, G. Hall, F. Lilly, R. M. Siervogel and S. S. Guo, "The Mini Nutritional Assessment and Body Composition in Healthy Adults," Nestlé Nutrition Workshop Series: Clinical \& Performance Programme, Vol. 1, 1999, pp. 13-22. doi:10.1159/000062956

[30] A. Saletti, E. Y. Lindgren, L. Johansson and T. Cederholm, "Nutritional Status According to Mini Nutritional Assessment in an Institutionalized Elderly Population in Sweden," Gerontology, Vol. 46, No. 3, 2000, pp. 139-145. doi:10.1159/000022149

[31] P. Tavitian, A. Tosello, L. Videau, L. Cornubert and J. J. Bonfil, "Etat Bucco-dentaire et Statut Nutritionnel: Étude Anthropo-Épidémiologique chez les Personnes Âgées," Antropo, Vol. 22, 2010, pp. 19-28.

www.didac.ehu.es/antropo

[32] L. J. Launer and T. Harris, "Weight, Height and Body Mass Index Distributions in Geographically and Ethnically Diverse Samples of Older Persons. Ad Hoc Committee on the Statistics of Anthropometry and Aging," Age and Ageing, Vol. 25, No. 4, 1996, pp. 300-306. doi:10.1093/ageing/25.4.300

[33] H. Klonoff-Cohen, E. L. Barrett-Connor and S. L. Edelstein, "Albumin Levels as a Predictor of Mortality in the Healthy Elderly," Journal of Clinical Epidemiology, Vol. 45, No. 3, 1992, pp. 207-212. doi:10.1016/0895-4356(92)90080-7

[34] B. Vellas, Y. Guigoz, P. J. Garry, F. Nourhashemi, D. 
Bennahum and S. Lauque, "The Mini Nutritional Assessment (MNA) and its Use in grading the Nutritional State of Elderly Patients," Nutrition, Vol. 15, No. 2, 1999, pp. 116-122. doi:10.1016/S0899-9007(98)00171-3

[35] Y. Guigoz and B. Vellas, "The Mini Nutritional Assess- ment (MNA) for Grading the Nutritional State of Elderly Patients: Presentation of the MNA, History and Validation," Nestlé Nutrition Workshop Serin Clinic Perform Programme, Vol. 1, 1999, pp. 3-12.

doi:10.1159/000062967 